\title{
Relationship Between HbAlc Level and Triglyceride/HDL Cholesterol Ratio and Triglyceride Glucose Index in Diabetes Patients
}

\section{Diyabetik Hastalarda HbAlc Düzeyinin Trigliserit/HDL Kolesterol Oranı ve Trigliserit Glikoz İndeksi Arasındaki İlişki}

\section{(D) Mustafa Asım Gedikli, (D Betül Sarı Kalın, (D) Ahmet Aktaș}

Sivas Cumhuriyet University Faculty of Medicine, Department of Internal Medicine, Sivas, Turkey

\section{Abstract}

Objective: To compare $\mathrm{HbA} 1 \mathrm{c}$ level with triglyceride/HDL cholesterol (TG/HDL-C) ratio and triglyceride glucose (TyG) Index and to show its relationship with $\mathrm{HbA1c}$ level.

Method: Our study was carried out retrospectively on patients who applied to the Department of General Internal Medicine, Sivas Cumhuriyet University Hospital, Turkey, between January 1, 2015 and January 1, 2020. The study is a retrospective review of 2.938 patients. HbA1c, triglyceride, and glucose values of the patients were recorded. TyG index and TG/ $\mathrm{HDL}-\mathrm{C}$ ) ratio were found by calculating. Patients were grouped according to their $\mathrm{HbA1c}$ levels, TyG index and triglyceride/HDL cholesterol ratios.

Results: We found that the TG/HDL-C ratio and the TyG index were statistically significantly lower as the HbA1c level decreased. When we grouped the patients according to their gender, we found that male patients had higher $\mathrm{HbA} 1 \mathrm{c}$, higher TyG index and TG/HDL-C ratio than female patients.

Conclusion: We found a positive correlation between $\mathrm{HbA} 1 \mathrm{c}$ levels and TG/HDL-C ratio and TyG index. Considering other studies in the literature, according to the results of our study, we predict an increased risk of coronary artery disease and cerebrovascular disease in patients with poor glycemic control.

Keywords: Diabetes mellitus, triglyceride glucose index, triglyceride/ HDL cholesterol ratio

\section{Öz}

Amaç: Çalışmamızdaki amacımız diyabetik hastalarda $\mathrm{HbA1c}$ düzeyini trigliserit/HDL kolesterol (TG/HDL-C) oranı ve trigliserit glikoz (TyG) indeksi ile karşılaştırmak ve HbA1c düzeyi ile ilişkisini göstermektir.

Yöntem: Çalışmamız 1 Ocak 2015-1 Ocak 2020 tarihleri arasında Sivas Cumhuriyet Üniversitesi Hastanesi, Genel Dahiliye Anabilim Dalı'na başvuran hastalar üzerinde retrospektif olarak yapılmıştır. Çalışmaya 2,938 hasta dahil edilmiştir. Hastaların HbA1c, trigliserit ve glikoz değerleri kaydedildi. TyG indeksi ve TG/HDL-C Oranı hesaplandı. Hastalar HbA1c düzeylerine göre gruplara ayrılarak TyG indeksi ve TG/HDL-C oranları karşılaştıııldı.

Bulgular: Hastalardaki HbA1c düzeyi arttıkça TG/HDL-C oranı ve TyG indeksinin istatistiksel olarak anlamlı derecede yüksek olduğu izlendi. Hastaları cinsiyetlerine göre grupladığımızda erkek hastaların HbA1c, TG/ HDL-K oranı ve TyG indeksinin kadın hastalara göre daha yüksek olduğu görüldü.

Sonuç: Çalışmamızda HbA1c düzeyleri ile TG/HDL-C oranı ve TyG indeksi arasında pozitif korelasyon bulduk. Literatürdeki diğer çalışmalar göz önünde bulundurularak, çalışmamızın sonuçlarına göre glisemik kontrolü kötü olan hastalarda koroner arter hastalığı ve serebrovasküler hastalık riskinde artış olduğunu öngörüyoruz.

Anahtar kelimeler: Diabetes mellitus, trigliserit glikoz indeksi, trigliserit/ HDL kolesterol oranı

\section{Introduction}

Diabetes mellitus (DM) is a chronic metabolic disease characterized by high blood sugar levels. It has been found that there is a decrease in insulin secretion or a resistance mechanism against insulin in peripheral tissues in its pathophysiology (1). When the high blood sugar level,

Address for Correspondence: Mustafa Asım Gedikli, Sivas Cumhuriyet University Faculty of Medicine, Department of Internal Medicine, Sivas, Turkey E-mail: asimgedikli@gmail.com ORCID: orcid.org/0000-0002-3494-7935 Received: 05.09.2021 Accepted: 09.02.2022

Cite this article as: Gedikli MS, Sarı Kalın B, Aktaş A. Relationship Between HbA1c Level and Triglyceride/HDL Cholesterol Ratio and Triglyceride Glucose Index in Diabetes Patients. Bagcilar Med Bull

${ }^{\circ}$ Copyright 2021 by the Health Sciences University Turkey, Bagcilar Training and Research Hospital Bagcilar Medical Bulletin published by Galenos Publishing House. 
which causes diabetes to occur, does not remain at target levels, some chronic complications such as retinopathy, nephropathy, peripheral neuropathy, autonomic neuropathy, and coronary artery disease (CAD) occur (2).

Hemoglobin Alc (HbAlc) is a marker that shows glucose tolerance and glucose regulation in diabetes, which is formed by slow and non-enzymatic glycosylation of hemoglobin. In laboratory tests, it is presented as the value obtained by dividing HbAlc into total hemoglobin. Today, HbAlc is used in blood sugar regulation in diabetic patients and in predicting the risk of complications that may occur due to diabetes (3).

Diabetic dyslipidemia is the most critical risk factor for DM patients with cardiovascular diseases (CVD). Serum Triglyceride/high-density lipoprotein cholesterol (TG/ HDL-C) ratio, which is accepted as the atherogenic plasma index, poses the most critical risk for CVD and metabolic syndrome $(4,5)$. A high TG/HDL-C ratio causes endothelial dysfunction. The TG/HDL-C ratio is high in patients with insulin resistance. Therefore, TG/HDL-C ratio can be considered as a determinant of glycemic control in obese patients with insulin resistance. When diabetic patients were compared according to their HbAlC levels, it was shown that patients with low HbAlC levels had approximately 3-4 times lower TG/HDL-C ratio. Based on these previous data, it can be said that high TG/HDL-C ratio may be closely associated with poor glycemic control and metabolic syndrome (6).

Triglyceride-glucose index (TyGindex) calculated according to fasting blood glucose (FBG) and triglyceride (TG) measurements can also be used as an indicator of insulin resistance (7). The TyG index is calculated as ln [fasting TG $(\mathrm{mg} / \mathrm{dL})$ x FBG $(\mathrm{mg} / \mathrm{dL}) / 2$ ]. It has been shown that the TyG index is a better marker in determining the diabetes risk than FPG and TG measurement in patients with blood glucose below 100 (8). When patients were compared according to their HbAlC levels, low HbAlC levels were found to have a lower TyG index. The lower the TyG index in individuals, the lower the risk of developing diabetes in those individuals. This increase is 2 times higher for men and 4 times higher for women. All these data conclude that as both TG/HDL-C ratio and TyG index increase, HbAlc level increases in diabetic patients $(9,10)$.

This study aimed to show whether there was a relationship between HbAlc levels and lipid profiles, TG/HDL-C ratio and TyG index in diabetic patients.

\section{Materials and Methods}

\section{The Type of the Study}

Our study was conducted as a single-center and retrospective.

\section{The Population and the Sample of the Study}

The results of a total of 2.938 patients who applied to the Internal Medicine Outpatient Clinic of Sivas Cumhuriyet University Medical Faculty Hospital between January 1, 2015 and January 1, 2020 were analyzed and recorded. The patients included in our study applied to the outpatient clinic for the first time.

The patients were divided into four groups according to their HbAlc levels. A healthy control group had HbAlc less than $6 \%$. Those with HbAlc higher than $6-8 \%, 8-10 \%$, and $10 \%$ were separated as the diabetic patient groups.

Diabetes was diagnosed according to the 75 gram oral glucose tolerance test (OGTT) results. The patients were administered 75 g OGTT after 8 hours of fasting. Diabetes was defined as those with a fasting plasma glucose result of $\geq 126$ or a plasma glucose result of $\geq 200$ at the $2^{\text {nd }}$ hour after 75 g OGTT (11).

Patients younger than 18 years of age, with a history of malignancy, hemoglobinopathy, lipid-lowering therapy, pregnancy, and anemia were excluded from the study.

\section{Laboratory Measurements}

Blood samples were taken from the antecubital vein after 8 hours of fasting. FBG, HbAlc, creatinine, AST, ALT, triglyceride, HDL, LDL, and total cholesterol levels were measured during the biochemical analysis.

The TG/HDL-C ratio was calculated by dividing the serum concentration of TG by HDL-C. Triglyceride and HDL results were measured in $\mathrm{mg} / \mathrm{dL}$. When calculating the TG/ HDL-C ratio, mg/dL was converted to $\mathrm{mmol} / \mathrm{L}$ according to the formula " $1 \mathrm{mg} / \mathrm{dL}=0.0555 \mathrm{mmol} / \mathrm{L}$ ". TyG index was calculated based on the formula Ln [TG (mg/dL) x FG (mg/ dL)/2] according to previous studies.

\section{Statistical Analysis}

Statistical comparisons were made using the statistical software package SPSS 22.0 (SPSS Inc., Chicago, IL, USA). The Kolmogorov-Smirnov and Kruskal-Wallis tests were used to test the fit of the data to the normal distribution. For both tests, the analyses were continued non-parametrically, since the data did not fit the normal distribution. The quantitative variables were expressed as mean \pm standard 
deviation and median (interquartile range: $5^{\text {th }}$ percentile$75^{\text {th }}$ percentile) while qualitative variables were given as frequencies and percentages. The significance level was accepted as 0.05 .

\section{Results}

Among 2.938 patients included in our study, the number of men was $1.213(41.3 \%)$, the number of women was 1725 (58.7\%), and the mean age was $57.42 \pm 13.22$ years. The mean HbAlc was $8.28 \pm 2.55$ (\%); triglyceride average was $1.99 \pm 1.25(\mathrm{mmol} / \mathrm{L})$; the mean HDL cholesterol was $1.13 \pm 0.31(\mathrm{mmol} / \mathrm{L})$; triglyceride/HDL cholesterol ratio was $2.02 \pm 1.77$; the mean triglyceride glucose index was $9.64 \pm 9.07$ (Table 1).

The average age of 561 patients, including 357 women (63.6\%) and 204 men (36.4\%) with HbAlc level below 6 (\%), was $52.93 \pm 13.8$ years; the mean triglyceride was 1.66 $0.94(\mathrm{mmol} / \mathrm{L})$; the mean HDL cholesterol was $1.22 \pm 0.34$ $(\mathrm{mmol} / \mathrm{L})$; triglyceride/HDL cholesterol ratio was $1.55 \pm 1.31$; the mean triglyceride glucose index was $4.78 \pm 2.94$. The average age of 1.006 patients, including 606 females (60.2\%) and 400 males (39.8\%) with HbAlc level between 6 (\%) and $8(\%)$, was $58.61 \pm 12.27$ years; the mean triglyceride value was $1.90 \pm 1.10(\mathrm{mmol} / \mathrm{L})$; the mean HDL cholesterol was $1.15 \pm 0.31(\mathrm{mmol} / \mathrm{L}) ;$ triglyceride/HDL cholesterol ratio was $1.87 \pm 1.72$; the mean triglyceride glucose index was $7.43 \pm 5.24$. The mean age of 684 patients, including 372 women (54.4\%) and 312 men (45.6\%) with HbAlc levels between 8 (\%) and 10 (\%), was $59.13 \pm 13.12$ years; the mean triglyceride was $2.10 \pm 1.31(\mathrm{mmol} / \mathrm{L})$; the mean

\begin{tabular}{ll}
$\begin{array}{l}\text { Table 1. Demographic characteristics of the patients } \\
\text { included in the study }\end{array}$ & Mean \\
\hline Gender & \\
Male & $1.213(41.3 \%)$ \\
Female & $1.725(58.7 \%)$ \\
Age (year) & $57.42 \pm 13.22$ \\
Fasting blood glucose (mg/dL) & $165.14 \pm 71.59$ \\
Creatinine (mg/dL) & $0.92 \pm 0.57$ \\
AST (mg/dL) & $21.37 \pm 11.65$ \\
ALT (mg/dL) & $24.16 \pm 17.63$ \\
HbA1c (\%) & $8.28 \pm 2.55$ \\
Triglyceride (mmol/L) & $1.99 \pm 1.25$ \\
HDL cholesterol (mmol/L) & $1.13 \pm 0.31$ \\
Triglycerid/HDL-cholesterol ratio & $2.02 \pm 1.77$ \\
Triglyceride glucose index & $9.64 \pm 9.07$ \\
\hline AST: Aspartate aminotransferase, ALT: Alanine & aminotransferase, HbA1c: \\
Hemoglobin A1c, HDL: High-density lipoprotein &
\end{tabular}

HDL cholesterol was $1.09 \pm 0.30(\mathrm{mmol} / \mathrm{L})$; triglyceride/ HDL cholesterol ratio was $2.15 \pm 1.67$; the mean triglyceride glucose index was found to be $11.22 \pm 8.85$. The average age of 687 patients, including 390 women (56.8\%) and 297 men (43.2\%) with HbAlc level above 10 (\%), was $57.63 \pm 13.37$ years; the mean triglyceride was $2.28 \pm 1.52(\mathrm{mmol} / \mathrm{L})$; the mean HDL cholesterol was $1.05 \pm 0.29(\mathrm{mmol} / \mathrm{L})$; triglyceride/HDL cholesterol ratio was $2.48 \pm 2.13$; the mean triglyceride glucose index was 15.26 \pm 12.91 (Table 2).

According to the HbAlc level, the patients were grouped as those with triglyceride/HDL cholesterol ratio lower than $6(\%)$, between 6-8 (\%), between 8-10 (\%) and over 10 (\%) (1.30; 1.50; 1.73, and 1.87, respectively) $(\mathrm{p}<0.001)$. Triglyceride glucose index was $4.07,6.05,8.84$, and 12.03 , respectively $(\mathrm{p}<0.001)$ (Table 3$)$.

When we grouped the patients by gender, the mean age of 1725 female patients was $57.48 \pm 13.46$ years, the mean HbAlc was $8.15 \pm 2.51$ (\%), the triglyceride average was $1.95 \pm 1.15(\mathrm{mmol} / \mathrm{L})$, the HDL cholesterol average was $1.19 \pm 0.33$ (mmol/L), triglyceride/HDL cholesterol ratio was $1.87 \pm 1.65$ and the average triglyceride glucose index was $9.23 \pm 8.37$. The mean age of 1213 male patients in the study was $57.34 \pm 12.85$ years, the mean $\mathrm{HbAlc}$ was $8.46 \pm 2.60$ (\%), the triglyceride average was $2.05 \pm 1.37(\mathrm{mmol} / \mathrm{L})$, the HDL cholesterol average was $1.03 \pm 0.27(\mathrm{mmol} / \mathrm{L})$, the triglyceride / HDL cholesterol ratio was $2.23 \pm 1.92$. The mean triglyceride glucose index was 1.92 and $10.22 \pm 9.96$ (Table 4 ).

\section{Discussion}

As the main result of our study, when the HbAlc levels increased in diabetic patients, that is, in patients with poor glycemic control, both triglyceride glucose index and triglyceride/HDL cholesterol ratio were found to be high. However, these relationships should be interpreted with caution because high triglycerides and a decrease in HDL cholesterol levels are seen as a characteristic features of insulin resistance and diabetes. Recent studies show that low HDL-C levels can exacerbate abnormal glucose metabolism (12). Triglyceride and HDL cholesterol levels may be affected by blood sugar regulation in patients with diabetes, as triglyceride levels and HDL C levels are thought to change due to insulin resistance (13).

Studies have shown that the triglyceride/HDL-C ratio is associated with cardiovascular risk, mainly associated with insulin resistance. Finally, they have shown that triglyceride/HDL-C may be a marker of glycemic control, especially in patients with type 2 diabetes $(14,15)$. In our 
Table 2. Characteristics of the patients according to HbA1c levels

\begin{tabular}{|c|c|c|c|c|}
\hline HbA1c & $<6$ & $6-8$ & $8-10$ & $>10$ \\
\hline \multicolumn{5}{|l|}{ Gender } \\
\hline Male & $204(36.4 \%)$ & $400(39.8 \%)$ & $312(45.6 \%)$ & $297(43.2 \%)$ \\
\hline Age (year) & $52.93 \pm 13.8$ & $58.61 \pm 12.27$ & $59.13 \pm 13.12$ & $57.63 \pm 13.37$ \\
\hline $\mathrm{FBG}(\mathrm{mg} / \mathrm{dL})$ & $102.47 \pm 23.98$ & $139.39 \pm 44.40$ & $185.79 \pm 58.70$ & $233.44 \pm 76.61$ \\
\hline ALT (mg/dL) & $22.47 \pm 15.23$ & $23.91 \pm 15.43$ & $24.63 \pm 18.43$ & $25.44 \pm 21.22$ \\
\hline Triglyceride (mmol/L) & $1.66 \pm 0.94$ & $1.90 \pm 1.10$ & $2.10 \pm 1.31$ & $2.28 \pm 1.52$ \\
\hline HDL cholesterol (mmol/L) & $1.22 \pm 0.34$ & $1.15 \pm 0.31$ & $1.09 \pm 0.30$ & $1.05 \pm 0.29$ \\
\hline Triglyceride/HDL-cholesterol ratio & $1.55 \pm 1.31$ & $1.87 \pm 1.72$ & $2.15 \pm 1.67$ & $2.48 \pm 2.13$ \\
\hline
\end{tabular}

FBG: Fasting blood glucose, AST: Aspartate aminotransferase, ALT: Alanine aminotransferase, HbA1c: Hemoglobin A1c, HDL: High-density lipoprotein

Table 3. Comparison of triglyceride/HDL cholesterol and triglyceride glucose indices according to HbA1c levels

\begin{tabular}{|c|c|c|c|c|c|}
\hline HbA1c & $<6$ & $6-8$ & $8-10$ & $>10$ & \\
\hline & median (IQR) & median (IQR) & median (IQR) & median (IQR) & $p$ \\
\hline Triglyceride/HDL-cholesterol ratio & 1.30 & 1.50 & 1.73 & 1.87 & $\mathrm{p}<0.001$ \\
\hline \multirow{2}{*}{ Triglyceride glucose index } & 4.07 & 6.05 & 8.84 & 12.03 & $\mathrm{p}<0.001$ \\
\hline & $2.86-5.93$ & $4.20-8.97$ & $5.97-13.63$ & $7.56-18.02$ & \\
\hline
\end{tabular}

HbA1c: Hemoglobin A1c, HDL: High-density lipoprotein, IQR: Interquartile range

Table 4. Examination of patient characteristics according to gender

\begin{tabular}{lll} 
Gender & $\begin{array}{l}\text { Male } \\
(\mathbf{n}=1.213)\end{array}$ & $\begin{array}{l}\text { Female } \\
(\mathbf{n = 1 . 7 2 5})\end{array}$ \\
\hline Age (year) & $57.34 \pm 12.85$ & $57.48 \pm 13.46$ \\
FBG $(\mathrm{mg} / \mathrm{dL})$ & $171.08 \pm 74.81$ & $160.95 \pm 68.94$ \\
Creatinine $(\mathrm{mg} / \mathrm{dL})$ & $1.04 \pm 0.59$ & $0.83 \pm 0.54$ \\
HbA1c $(\%)$ & $8.46 \pm 2.60$ & $8.15 \pm 2.51$ \\
Triglyceride (mmol/L) & $2.05 \pm 1.37$ & $1.95 \pm 1.15$ \\
HDL cholesterol (mmol/L) & $1.03 \pm 0.27$ & $1.19 \pm 0.33$ \\
Triglyceride/HDL-cholesterol & $2.23 \pm 1.92$ & $1.87 \pm 1.65$ \\
ratio & & \\
Triglyceride glucose index & $10.22 \pm 9.96$ & $9.23 \pm 8.37$
\end{tabular}

FBG: Fasting blood glucose, HbA1c: Hemoglobin A1c, HDL: High-density lipoprotein

study, the ratio of triglyceride/HDL cholesterol was found to be higher as the HbAlc level increased, and it was found to be affected by poor glycemic control. In addition, our study found that the triglyceride/HDL cholesterol ratio was higher in male patients than in female patients.

In a study conducted by da Silva et al. (16), it was shown to be associated with a higher prevalence of CAD in patients with a high TyG index, and in this study, they showed that the TyG index could be used as a marker for atherosclerosis. Recent studies show that the TyG index is widely used as a marker of insulin resistance. In the study conducted by Luo et al. (17), it has been shown that a high TyG index is associated with an increased risk of cardiac and cerebrovascular events in patients with ST-elevation myocardial infarction undergoing percutaneous coronary intervention. In the study conducted by Shi et al. (18), they showed an increase in the risk of ischemic stroke parallel to the increase in the TyG index. In another study conducted by Zhao et al. (8), they showed that a high TyG index was significantly associated with a higher risk of microvascular damage and arterial stiffness.

In the light of previous studies, it was seen that triglyceride/ HDL cholesterol ratio and high TyG index were associated with increased poor glycemic control, increased risk of cerebrovascular disease, and increased risk of $\operatorname{CAD}(19,20)$. In our study, we found high triglyceride/HDL cholesterol and TyG index in patients with poor glycemic control and high HbAlc levels. And the increase in these rates seems to increase as the HbAlc level rises.

\section{Study Limitations}

Since our study was planned as a retrospective study, we only recorded the laboratory values of the patients in the system, 
but we could not question and evaluate the patients in terms of current cardiac risk or cerebrovascular disease risk.

\section{Conclusion}

Triglyceride/HDL cholesterol ratio and TyG index are associated with insulin resistance, and in our study, we retrospectively demonstrated a poor glycemic index, that is, the increase in HbAlc level, and the triglyceride/ HDL cholesterol ratio and TyG index. Further prospective studies are needed to demonstrate that the TyG index and triglyceride/HDL cholesterol ratio are associated with increased risk of cardiac and cerebrovascular disease in diabetic patients.

\section{Ethics}

Ethics Committee Approval: The study was approved by the Ethics Committee of Clinical Studies at xx University by the date of 08.07.2020 and the number of 2020-07/25. Our study was carried out in accordance with the principles of the Declaration of Helsinki.

Informed Consent: An informed consent form was obtained from the patients.

Peer-review: Externally peer-reviewed.

\section{Authorship Contributions}

Concept:M.A.G., Design:M.A.G., B.S.K., A.A., Data Collection or Processing: M.A.G., A.A., Analysis or Interpretation: B.S.K., A.A., Literature Search: M.A.G., B.S.K., A.A., Writing: M.A.G., A.A.

Conflict of Interest: No conflict of interest was declared by the authors.

Financial Disclosure: The authors declared that this study received no financial support.

\section{References}

1. Valaiyapathi B, Gower B, Ashraf AP. Pathophysiology of type 2 diabetes in children and adolescents. Curr Diabetes Rev 2020;16(3):220-229.

2. Ryder RE. Real-world diabetes prevention: from theory to practice. Lancet Diabetes Endocrinol 2018;6(10):756-757.

3. Tucker LA. Limited Agreement between Classifications of Diabetes and Prediabetes Resulting from the OGTT, Hemoglobin Alc, and Fasting Glucose Tests in 7412 U.S. Adults. J Clin Med 2020;9(7):2207.

4. Ardahanli I, Celik M, Takir M. Relationship between Neutrophil/ Lymphocyte Ratio and Cardiometabolic Values in Patients with Prediabetes. Glob J Endocrinol Metab 2018;2(4):1-4.

5. Aktaş A, Gedikli MA, Şahin A. Ailesel Akdeniz Ateşi hastalarının trigliserid/yüksek dansiteli lipoprotein oranına göre karşılaştırılması. ADYÜ Sağlık Bilimleri Derg 2021;7(1):20-25.
6. Babic N, Valjevac A, Zaciragic A, Avdagic N, Zukic S, Hasic S. The Triglyceride/HDL Ratio and Triglyceride Glucose Index as Predictors of Glycemic Control in Patients with Diabetes Mellitus Type 2. Med Arch 2019;73(3):163-168.

7. Navarro-González D, Sánchez-Íñigo L, Pastrana-Delgado J, Fernández-Montero A, Martinez JA. Triglyceride-glucose index (TyG index) in comparison with fasting plasma glucose improved diabetes prediction in patients with normal fasting glucose: The Vascular-Metabolic CUN cohort. Prev Med 2016;86:99-105.

8. Zhao S, Yu S, Chi C, Fan X, Tang J, Ji H, et al. Association between macro-and microvascular damage and the triglyceride glucose index in community-dwelling elderly individuals: the Northern Shanghai Study. Cardiovasc Diabetol 2019;18(1):95.

9. Park GM, Cho YR, Won KB, Yang YJ, Park S, Ann SH, et al. Triglyceride glucose index is a useful marker for predicting subclinical coronary artery disease in the absence of traditional risk factors. Lipids Health Dis 2020;19(1):1-7.

10. Hameed EK. TyG index a promising biomarker for glycemic control in type 2 diabetes mellitus. Diabetes Metab Syndr 2019;13(1):560-563.

11. American Diabetes Association. 2. Classification and diagnosis of diabetes: Standards of Medical Care in Diabetes-2021. Diabetes Care 2021;44(Suppl 1):S15-S33.

12. Zhang Y, Qin P, Lou Y, Zhao P, Li X, Qie R, et al. Association of TG/ HDLC ratio trajectory and risk of type 2 diabetes: A retrospective cohort study in China. J Diabetes 2020. doi: 10.1111/17530407.13123.

13. Bjornstad P, Eckel RH. Pathogenesis of lipid disorders in insulin resistance: a brief review. Curr Diab Rep 2018;18(12):127.

14. Quispe R, Martin SS, Jones SR. Triglycerides to high-density lipoprotein-cholesterol ratio, glycemic control and cardiovascular risk in obese patients with type 2 diabetes. Curr Opin Endocrinol Diabetes Obes 2016;23(2):150-156.

15. Wen J, Huang Y, Lu Y, Yuan H. Associations of non-high-density lipoprotein cholesterol, triglycerides and the total cholesterol/ HDL-c ratio with arterial stiffness independent of low-density lipoprotein cholesterol in a Chinese population. Hypertens Res 2019;42(8):1223-1230.

16. da Silva A, Caldas APS, Hermsdorff HHM, Bersch-Ferreira ÂC, Torreglosa CR, Weber B, et al. Triglyceride-glucose index is associated with symptomatic coronary artery disease in patients in secondary care. Cardiovasc Diabetol 2019;18(1):89.

17. Luo E, Wang D, Yan G, Qiao Y, Liu B, Hou J, et al. High triglycerideglucose index is associated with poor prognosis in patients with acute ST-elevation myocardial infarction after percutaneous coronary intervention. Cardiovasc Diabetol 2019;18(1):150.

18. Shi W, Xing L, Jing L, Tian Y, Yan H, Sun Q, et al. Value of triglyceride-glucose index for the estimation of ischemic stroke risk: Insights from a general population. Nutr Metab Cardiovasc Dis 2020;30(2):245-253.

19. Zorlu M, Helvacı A, Kıskaç M, Yolbaș S, Ardıç C, Oran M, et al. Silent myocardial ischemia and related risk factors in patients with type 2 diabetes mellitus. Dicle Med J 2010;37(2):140-124.

20. Aktaş A, Gedikli MA, Kara C, Bakır MR. Can the Triglyceride/HDL Ratio in Chronic Kidney Disease be Predictive of Cardiac Risk? F.U. Med.J.Health.Sci. 2021;35(1):35-39. 